\title{
Shakespeare, The Spanish Armada and the Mississippi
}

\section{C.W.R.D. Moseley}

This essay is concerned with Shakespeare's huge shadow - especially, during and after the eighteenth century, the shadow of Hamlet. But Shakespeare too was aware of shadows, and in Midsummer Night's Dream the burlesque in the mechanicals' play of Pyramus and Thisbe is an ironic take on well-worn conventions and how easily they could lose potency. Similarly, the Player's speech in Hamlet is a perfectly serious, even respectful, acknowledgement of that same stock in trade to which, nevertheless, this new play sits lightly. The unwritten, unspoken subtitle that screams at you in Hamlet is "Not the Spanish Tragedy": and Hamlet's own shadow is so long that it may be resented as well as used, and even done to death.

So this essay will look at two examples of how this issue might be negotiated by two writers in very different cultural epistemes, Sheridan in The Critic (1779) and Mark Twain in Huckleberry Finn (1884).

But, by way of Introduction, consider two visual examples of how artists can chafe against, interrogate, but cannot quite reject their

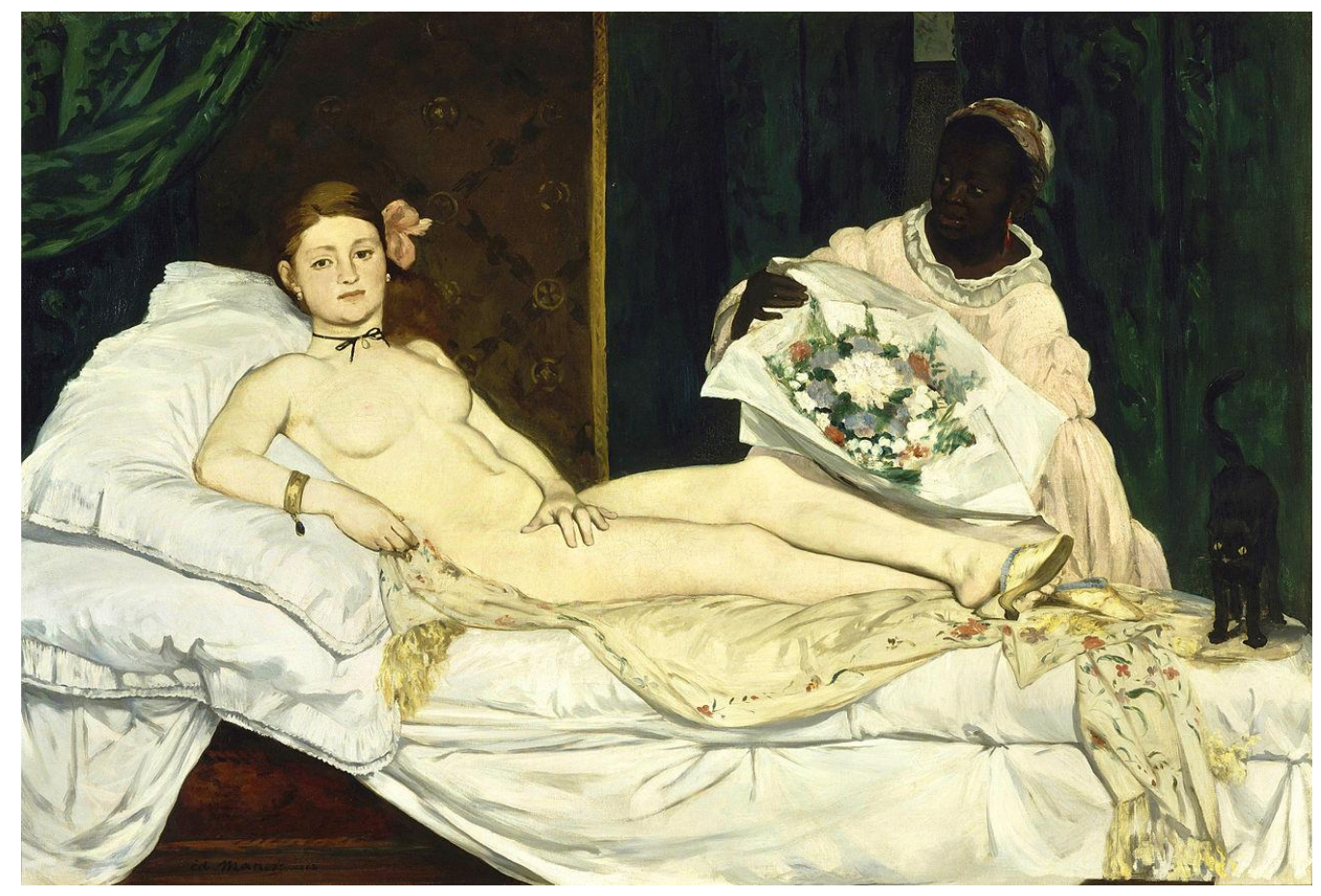

Figure 1 Edouard Manet Olympias 1865 


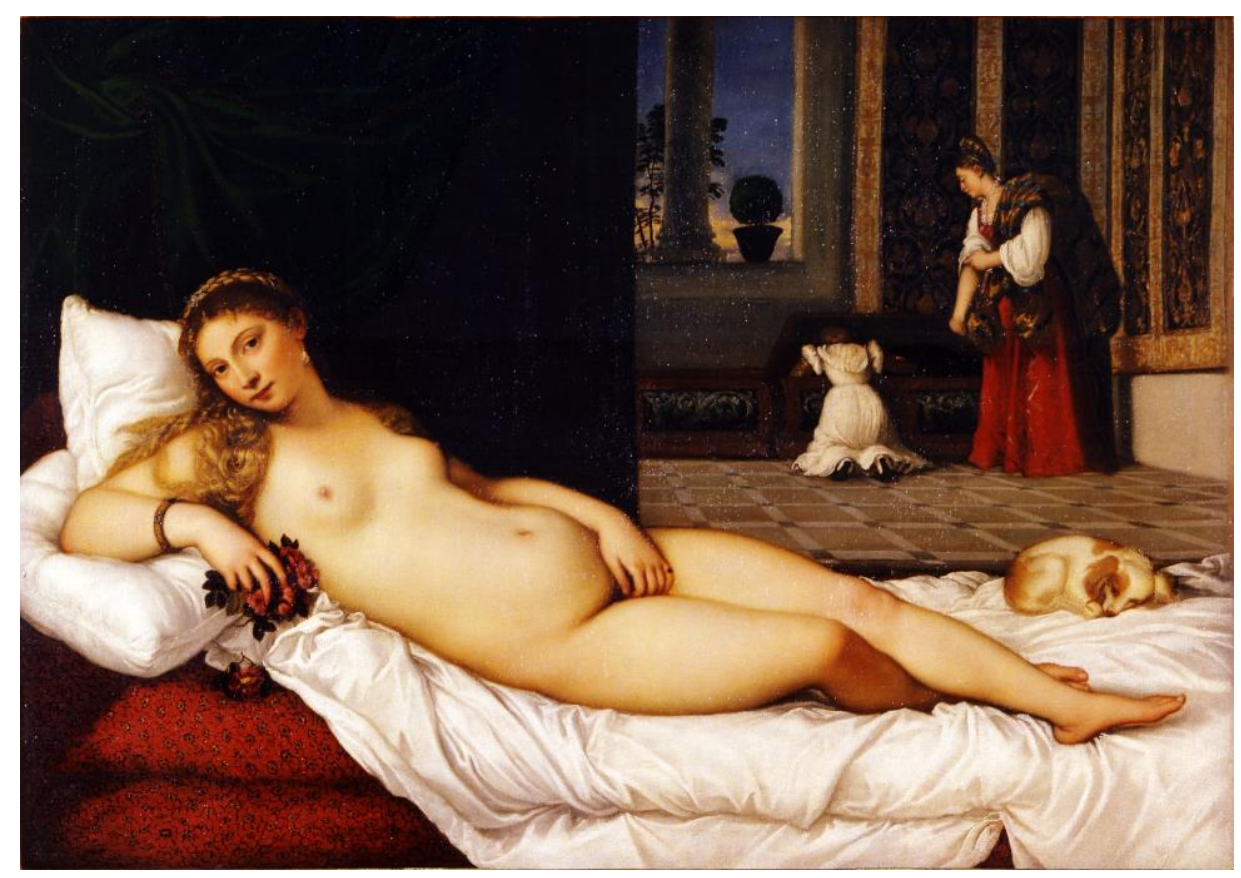

Figure 2 Titian Venus of Urbino 1538

inheritance (Figures 1 and 2). Think of the huge amount of classicising architecture and art in the decades around and after the French revolution: the Empire style, the vocabulary of the Directoire, the paintings of Jacques Louis David, and so on. But this is the very time when radical differences between the inherited and the actual, the present day, are beginning to be obvious, with industrialisation and all its consequences. So a painting likes Manet's Olympias (1863), a painting of a whore, asks a serious question about that painting on which it puns, Titian's Venus of Urbino (1538): what relevance does that style, that inheritance, that fiction - and the mythology on which it is built - have in an age of railways and steam and the money nexus and the monstrous growth of cities like London and Paris?

But, much more cruelly: in 1842 Honore Daumier takes the gift that bright eyed Athene gave much enduring Odysseus and faithful Penelope when they at last are reunited and blows a raspberry at it (Figure 3). This is the "truth:" what has all that nonsense to do with the "real world"?

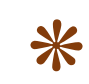




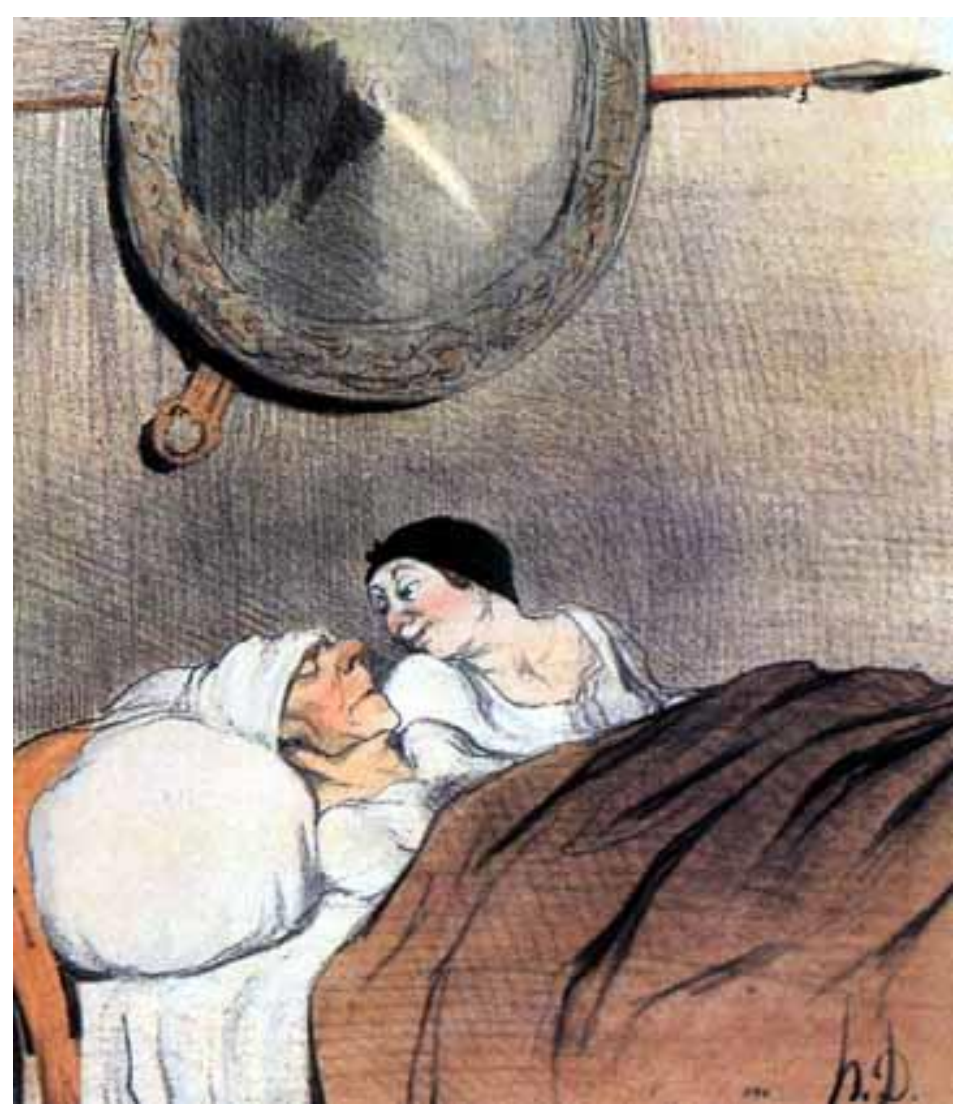

Figure 3 Honore Daumier Odysseus and Penelope 1842

at prevailing dramatic conventions - for example in George Villiers' The Rehearsal (1671) which so annoyed Dryden. Sheridan exploits this: Puff's play, the Spanish Armada, is a tissue of the most worn stage clichés of the 1770s, but Sheridan also suggests that many theatrical absurdities are problems inherent in the nature of drama as an agreed meta-reality within the reality of watching it. (Indeed, it is not absurd to suggest that the fundamental conceit of Sheridan's play is an audience watching an audience and made aware of themselves as an audience.) But he also suggests that these problems reach right back to Hamlet, already the most familiar of Elizabethan plays and the great exemplar of the "play within a

Sheridan's The Critic, or, A Tragedy Rehears'd: a Farce (1779) is a wonderfully funny play, but it has a serious point: how do you get out from under Shakespeare's shadow, and escape from what were once useful conventions for him, but which are now empty clichés? The play's intimate relation to Hamlet which preceded it in the first performance is used to explore what the relation might be between drama and what for want of a better word I shall call the consenting audience. How is that audience manipulated into consent by the art of Puffing?

The "play within a play," powerfully used of course in the mirrored quasi-realities of Hamlet, had often been used to provoke a critical glance play" strategy. Echoes of that play pervade The Spanish Armada, and modern audiences easily forget that Hamlet, as the main piece preceding The Critic on that first night, provided a context for it. The verbal and visual echoes acquire added ironic point if the experience of Hamlet is so fresh. But it is important to realise that Sheridan is not parodying Hamlet: rather, Hamlet is used to show up Puff's play. Sheridan invites his audience to consider the theatrical fashions they take for granted by deconstructing conventions that are usually accepted in earnest, without thought, and nowhere more so than in high tragedy. Thus, the burlesque of the exalted 
sharpens Sheridan's audience's awareness of their own relation to theatre's artificial world.

Sheridan skilfully steers between homage and ridicule throughout. He balances criticism of contemporary theatrical techniques with genuine regard for the standards set in Shakespeare's time. Tilburina does not ridicule Ophelia, rather the other way round. The most common absurdities attacked are the contrived devices to develop plot: disguise, overhearing, unnecessary exposition and conspiratorial modes of address (such as the aside and soliloquy) are all made ridiculous. The Spanish Armada, a patchwork of comic incongruities, highlights how easily elevated tragedy tips over into farce if the limitations of dramatic representation are not acknowledged. In Puff's opening scene, Sir Christopher Hatton declares "There is a question which I yet must ask - / A question which I never asked before." (2.1.9394). Sir Walter then gives a verbose exposition, the main points of which must be, of course, already familiar to Hatton. Dangle and Sneer's interjections make the artificiality seem ludicrous, and yet Shakespeare's audiences were similarly "very much obleeged" (Dangle, 2.1.166) to Marcellus for extracting a potted history of Danish politics from Horatio in Hamlet's opening scene. Shakespeare's model indeed teeters on the brink of plausibility, and Sheridan's burlesque shows how easily tragedy could trip up into the laughable. A good performance, indeed, of Hamlet would command that acceptance of convention that needs to accompany such an unrealistic exposition, but by stressing its potential absurdity, Sheridan highlights the essential complicit relationship between audience, actors and playwright. The corollary that this relationship is not always warranted is almost certainly directed at the work of Sheridan's contemporaries, most notably Richard Cumberland, whom Sheridan portrayed with "directly and grossly personal" ridicule as Sir Fretful Plagiary. (School for Scandal and other Plays, ed. E. Rump, Harmondsworth: Penguin, 1988, p. xl). Cumberland's recent (1778) tragedy The Battle of Hastings seems to inform some of The Spanish Armada's most clumsy elements of plot.

Sheridan guys other worn-out yet still too current conventions as well: for example, the stichomythic exchange, supposedly to increase tension, and the idiom of madness. The "small sword logic" (Puff, 2.1.376) of the nonsensical stichomythia between Tilburina and her father in 2.1 is equated with fencing, a metaphor leading us again to Hamlet. For by quoting Osric ("a palpable hit," 2.1.395) Sheridan invites comparison with the stichomythic exchange between Laertes and Hamlet at a moment of great intensity in Hamlet's final scene. There the momentum reflects, and heightens, the tension of the fatal duel. In contrast, stichomythia in The Spanish Armada is meaningless in position, context and purpose. Similarly, Tilburina's madness in 3.1 is expressed in what had become, almost perfunctorily, a distinctive mode. An hour or two earlier the audience of The Critic would have been moved by Ophelia's white dress, distressed hair, "mangled" metre (Puff, 3.1.251) and fragmented, nonsensical snippets of songs and speech. Now Sheridan, by isolating and exaggerating each of those elements in an already ridiculous heroine, invites his audience 
not simply to laugh at her and her utterance but to question why and how they took those formulae perfectly seriously in the first place. Ophelia's madness is, arguably, potentially comic - after all, a visit to Bedlam to laugh at the inmates was a perfectly acceptable Sunday afternoon diversion in that century - but Shakespeare, a master of generic instability if anyone ever was, made a dramatis persona ${ }^{1}$ who successfully reconciles the pathetic, even tragic, with the laughable - as, indeed, the whole play could be argued to do. Sheridan's caricature crystallises and isolates every overused aspect of Shakespeare's original model but the attack is not on the model itself but on incompetent attempts to manage the relationship between the tragic and the comic in the theatre of his own time, and the capacity of what once was deeply expressive now to inhibit and trivialise proper expression. To put it another way, the attempt to recreate the essence of tragedy from its accidents, without realising that without essence one only has disiecta membra. Mechanical use of conventions, however grand their ancestry, will not speak to a world wholly different from that in which they were vital.

Overblown rhetorical embellishment is equally one of the targets, and the overly mannered acting of the tragic mode in his day: the sort of body language we glimpse in prints of the time, even in Emma Hart's Attitudes. The elevated poignancy of tragedy may well demand high utterance, and grand body language, which can be beautifully realised in accord with the spirit of the tragic action, but Sheridan's satire highlights how poor imitation merely of such linguistic intensity, a slavish following of convention, is disastrous. This is clear during Tilburina's opening speech in 2.2; the ragbag of tropes from exalted sources descends entirely into bathos. When Puff's heroine appears one would indeed expect that she will reinforce The Spanish Armada's parodic tenor, established through the flatfooted dialogue of its martial heroes. Sheridan exploits this expectation, teasingly having Puff build anticipation of Tilburina's entrance while at the same time leading us to expect the bathos we get. A change in atmosphere is signalled by Handel's minuet from Ariadne, an aural hint of another overused convention, before Tilburina wafts onstage in exaggerated distress with her confidante. (Even that confidante - Puff has given her no exit line, to the actress' vocal annoyance - is a cliché, deriving from neoclassical drama.)

...Puff. It shows that Tilburina is coming ; nothing introduces you a heroine like soft music. Here she comes!

Dang. And her confidant, I suppose?

Puff. To be sure! Here they are inconsolable to the minuet in Ariadne!

(Soft music)

Enter Tilburina and Confidante.

Tilb. Now has the whispering breath of gentle morn

Bid Nature's voice and Nature's beauty rise; While orient Phoebus, with unborrowed hues,

Clothes the waked loveliness which all night slept

In heavenly drapery! Darkness is fled.

Now flowers unfold their beauties to the sun. 
And, blushing, kiss the beam he sends to wake them -

The striped carnation, and the guarded rose. The vulgar wallflower, and smart gillyflower. The polyanthus mean - the dapper daisy, Sweet-William, and sweet marjoram - and all

The tribe of single and of double pinks!

Now, too, the feathered warblers tune their notes

Around, and charm the listening grove. The lark!

The linnet! chaffinch! bullfinch! goldfinch! green-finch!

But 0 , to me no joy can they afford!

Nor rose, nor wallflower, nor smart gillyflower.

Nor polyanthus mean, nor dapper daisy, Nor William sweet, nor marjoram - nor lark, Linnet, nor all the finches of the grove! Puff. Your white handkerchief, madam! Tilb. I thought, sir, I wasn't to use that till "heart rending woe"

Puff. 0 yes, madam, at "the finches of the grove," if you please...

"Now has the whispering breath of gentle morn" (2.1.280); such words could be spoken, quite seriously, in a myriad plays. Her language remains elevated but it is a tissue of stylistic tics. And they are hardly appropriate: her first lines, for example, suggest an aubade whereas Tilburina is supposedly "inconsolable" having lost her love (2.1.278). Sheridan's parody reaches its next level a few lines later (at line 285), when Tilburina embarks on her catalogue of flowers: that is after all what one does if one is mad. This list, increasingly meaningless and mechanical, recalls several of Shakespeare's heroines: Cordelia's description of her father's deranged appearance in King Lear, Perdita's pastoral charm in A Winter's Tale and most obviously Ophelia's madness in Act 4 of Hamlet. Tilburina struggles for appropriate adjectives, resorting (289) to trite alliteration ("dapper daisy") and in line 290 to mere repetition, which encases a punning nod to the paradigm that Sheridan has subverted ("Sweet William and sweet marjoram"). The second part of her speech, a farcical repetition of already ridiculous tropes, builds to a parodic climax in her ridiculous reprise of the finches in line 294. The dramatic intensity Puff claims for Tilburina's supposed distress is in clear antithesis to the hollow sense of her words, an ironic gap heightened by Puff's advice at the most inapposite point to pull out her white handkerchief. By taking words and phrases of out of their original poetic or dramatic matrix and merely pasting them together, Sheridan disrupts whatever emotions might have gone with them originally and exposes their inherent absurdity. And this point I shall return to later.

So Tilburina's speech deftly balances, if precariously, on the distinction between burlesque and travesty. This finesse dis-tinguishes The Critic from Buckingham's The Rehearsal, the template which it eventually superseded in popularity. That clever satire of John Dryden and the conventions of heroic tragedy did not extend its vision beyond a contemporary focus. Sheridan, by contrast, carefully hints at the plausible magnificence of the tragic mode before 
spiralling into mock-heroic farce, and this constitutes a crucial difference in the strategies of the two playwrights. Sheridan's prime target may well be the insipid dullness of theatre in his own time, but by underlining his mockery of contemporary writing with allusions to The Rehearsal alongside Shakespeare, he establishes a relationship of continuity between Elizabethan, Restoration and Georgian modes. When Sheridan invokes Buckingham's character Bayes, it reminds his audience that absurd theatrical productions are not exclusive to the 1770s. Three-line soliloquies, unnecessary expositions, nonsensical stichomythic exchanges and laboured rhetorical flourishes characterise Bayes' writing just as they do Puff's. But when Sheridan reaches back beyond the Restoration to Shakespeare, he identifies the point of origin for many of these absurdities when they were not absurd. Here he goes further than Villiers for he shows that dramatic conventions make a needed contribution to the language of theatre. Both playwright and audience need to accept the symbolic and metaphoric representation of complicated human experience. Shakespeare clearly accepted this in the self-referential metatheatricality of most of his plays, not least his cross-dressing comedies, or the romances, the essence of which is a playful awareness of the material aspects of performance. Sheridan, like Buckingham, ridicules bad writers, but his Shakespearean allusions pay tribute to a playwright who did successfully negotiate the inherent artificiality of his medium.

Sheridan did not intend to make Shakespeare qua Shakespeare the target of The Critic's satire. Certainly one could criticise Shakespeare's tragedies for their exaggerated or repetitious elements - Ben Jonson might well have done, and Thomas Rymer did - and certainly they can, if we are in a dyspeptic mood, at times and in some productions veer towards the ridiculous rather than the noble. But in recognising this, Sheridan concedes that Shakespeare's tragedies set the parameters of artificiality and dignity for their mode, parameters which should not and cannot be placed under stress. But while they worked then, they do not work now. Indeed, one might argue that the echoes of Hamlet stress both the vapidity of Puff's play and reinforce the high seriousness of what had been watched an hour or so earlier - rather as Aristophanes might reinforce Euripides. The Critic, indeed is a more sophisticated and accomplished exploration of dramatic conventions and how they are watched than any of its predecessors. Even David Garrick, in A Peep Behind the Curtain (1767), disparaging the undiscriminating audiences that would admire Glib's farcical Italian Operetta as readily as Shakespearean tragedy, only sent up current theatrical vogues and pretensions. Sheridan by contrast widened the focus and brought into relief the fine line between the sublime and the ridiculous: and the necessity for a new age to acknowledge its past but also to accept the need not to be bound to or by it.

\section{*}

The shadow of Shakespeare: it is interesting that the Romantic poets all had to have a go at the 5act "Shakespearean" tragedy - as if to prove their poetic manhood, even if, like Wordsworth's The 
Borderers the results are dire. (Interestingly, this

is Wordsworth's first major work, written between 1796 and 1798.) That shadow extends to the New World. Mark Twain's Huckleberry Finn (1884) has an episode (chapters 19-21) crucial to the symbolic journey on the raft down the Mississippi, where Shakespeare, is so to speak, current.

The deracinated Huck and the runaway nigger Jim - so Twain calls him, and it is im- portant that that stereotype be recognised - are loose on the Mother of Waters, on a raft: the picaresque potential of such a journey is obvious and is indeed used, but so is the way these two boys and their journey are a symbol of an America, twenty years after the Civil War, still trying to find an identity of its own which will not simply be a pale shadow of what has been left behind. The important episode when the boys meet the two conmen in Arkansas

\title{
Edmund Kean the elder, of the Royal Haymarket Theatre, White-chapel, Pudding Lane, Piccadilly, London, and the Royal Continental Theatres, in their sublime Shaksperean Spectacle entitled
}

\section{THE BALCONY SCENE} in

\section{ROMEO ANDJUUIET！！～ \\ Romeo . . . . . . . . . Mr. Garrick \\ Juliet. . . . . . . . . . . . . Mr. Kean}

Assisted by the whole strength of the company!

New costumes, new scenery, new appointments!

Also:

The thrilling, masterly, and blood-curdling Broad-sword conflict In

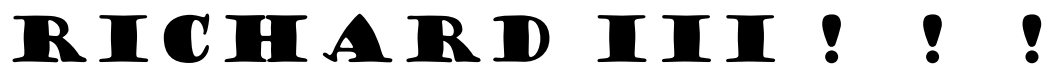

Richard III . . . . . . . . Mr. Garrick.'

Richmond . . . . . . . . Mr. Kean.

also:

(by special request,)

\section{HAMLET'S IMMOORTAL SOLILOQUY！ ! \\ BY THE ILLUSTRIOUS KEAN! DONE BY HIM 300 CONSECUTIVE NIGHTS IN PARIS!}

\author{
For One Night Only.
}


exemplifies many of the themes of the novel: the duke (of Bridgewater) and the soi-disant King of France remind us parodically of the power structures of the old Europe America has rejected, but their imposture is almost welcomed by their naïve victims. For this is a society with no identity or coherence.

Worthless, pitiful, foolish people, without courage, as Colonel Sherburn says, to organise a proper lynching - what price justice, indeed? And the only person claiming and getting any respect is the man with a gun, Colonel Sherburn. Behind the comedy Twain gives us a pretty grim picture, for these are human beings, lost in the stream of time. In one town the Duke and the King hire a theatre and bill themselves as Edmund Kean and David Garrick. It is all about money, of course, and neither has any idea of a play: their playbill offers the balcony scene from Romeo, the fight between Richard III and Richmond, and Hamlet's soliloquy, as if each were complete.

But what the King can remember as "Hamlet's soliloquy" - which, indeed? - is bizarre, and must be in fact the weirdest farrago of Shakespeare ever (Chapter 21):

He told us to give attention. Then he strikes a most noble attitude, with one leg shoved forwards, and his arras stretched away up, and his head tilted back, looking up at the sky; and then he begins to rip and rave and grit his teeth; and after that, all through his speech he howled, and spread around, and swelled up his chest, and just knocked the spots out of any acting ever I see before.
This is the speech - I learned it, easy enough, while he was learning it to the king:

To be, or not to be; that is the bare bodkin

That makes calamity of so long life;

For who would fardels bear, till Birnam Wood do come to Dunsinane,

But that the fear of something after death

Murders the innocent sleep,

Great nature's second course,

And makes us rather sling the arrows of outrageous fortune

Than fly to others that we know not of.

There's the respect must give us pause:

Wake Duncan with thy knocking! I would thou couldst;

For who would bear the whips and scorns of time,

The oppressor's wrong, the proud man's contumely,

The law's delay, and the quietus which his pangs might take,

in the dead waste and middle of the night, when churchyards yawn

In customary suits of solemn black,

But that the undiscovered country from whose bourne no traveller returns,

Breathes forth contagion on the world,

And thus the native hue of resolution, like the poor cat i' the adage, Is sicklied o'er with care,

And all the clouds that lowered o'er our housetops, With this regard their currents turn awry, And lose the name of action. 'Tis a consummation devoutly to be wished. But soft you, the fair

Ophelia: 
Ope not thy ponderous and marble jaws,

But get thee to a nunnery-go!

What is going on? Yes, a rag bag of garbled memory, to be sure. But I think a much deeper question is being posed: this was important once, it is still a cultural marker, but it is meaningless to those who might be gulled into parting with their 50 cents and it is meaningless to the performer. Its time has passed if its authority has not. The raft is carried along on the stream, and new beginnings - for the slave running to freedom, for the orphan tramp, for the barely civilised communities - will take no account of Duke or Kings - who were frauds anyway, says Huck - or of Shakespeare: indeed, should not. Twain seems to me to have had a serious unease about the European inheritance, not only here, but also with Europe's most deeply embedded families of narrative: $A$ Connecticut Yankee in King Arthur's Court, (1889) is tasteless, and ludicrous, but it makes the same serious point. Daumier had good company. I can't do better then close with Walt Whitman:

\section{Song of the Exposition}

AFTER all, not to create only, or found only,

But to bring, perhaps from afar, what is already founded,

To give it our own identity, average, limitless, free;

To fill the gross, the torpid bulk with vital religious fire;

Not to repel or destroy, so much as accept, fuse, rehabilitate;

To obey, as well as command - to follow, more than to lead;

These also are the lessons of our New World;

—While how little the New, after all—how much the Old, Old World!

Long, long, long, has the grass been growing,

Long and long has the rain been falling,

Long has the globe been rolling round.

Come, Muse, migrate from Greece and Ionia;

Cross out, please, those immensely overpaid accounts, That matter of Troy, and Achilles' wrath, and Eneas', Odysseus' wanderings;

Placard "Removed" and "To Let" on the rocks of your snowy Parnassus; 15 Repeat at Jerusalem-place the notice high on Jaffa's gate, and on Mount Moriah;

The same on the walls of your Gothic European Cathedrals, and German, French and Spanish Castles;

For know a better, fresher, busier sphere-a wide, untried domain awaits, demands you.

Which is a long way from where most of us English started, with school editions like the Warwick Shakespeare (1839-1938) purged of everything that might bring a blush to the cheek of a young person. 


\title{
Works Cited
}

Sheridan, Richard Brinsley. School for Scandal and other Plays. Rump, E. Ed. Harmondsworth: Penguin, 1988.

Twain, Mark. Tom Sawyer and Huckleberry Finn. London and Glasgow: Collins, 1961

Whitman, Walt. Leaves of Grass (1900). Bartleby.com. 24. August, 2015.

\section{Image Credits}

Figures 1, 2, and 3: @Wikimedia Commons

\begin{abstract}
${ }^{1}$ I purposely avoid the use of the word "character" because it begs a lot of questions and implies ways of seeing, (and reading) plays that long postdate Shakespeare. See my essay "Judicious, sharp spectators? Form, pattern and audience in early modern theatre: some problems," Cahiers Elizabethains, 85 (Spring 2014), pp.8-20; my English Renaissance Drama: A very Short introduction to Theatre and Theatres in Shakespeare's Time (Tirril: Humanities e-books, 2008) pp.55ff.; and my forthcoming essay, "Shakespeare's Hypocrites," which develops ideas in a paper given at the meeting of the Hungarian Shakespeare Conference, Szeged September, 2013.
\end{abstract}

